(c) 2015, publisher and licensee JDDT, This is an Open Access article which permits unrestricted noncommercial use, provided the original work is properly cited

\title{
RESEARCHARTICLE
}

\section{INCIDENCE OF PRESENCE OF H. PYLORI IN CASES OF CHOLECYSTITIS AND CHOLELITHIASIS IN A RURAL MEDICAL COLLEGE \& HOSPITAL} Pradeep Kumar Chaudhary ${ }^{1}$, Subhash Goyal ${ }^{1}$, Nanak Chand Mahajan ${ }^{2}$, OSaurabh Kansal $^{3}$, Priti Sinha ${ }^{4}$

${ }^{1}$ Deptt. of General Surgery, Maharishi Markandeshwar Institute of Medical Sci \& Research, Mullana, Haryana, India

${ }^{2}$ Deptt. of Pathology, Maharishi Markandeshwar Institute of Medical Sci \& Research, Mullana, Haryana, India

${ }^{3}$ Deptt. of Pharmacology, Subharti Medical College, Meerut, U.P., India

${ }^{4}$ Deptt. of Anatomy, Subhrti Medical College, Meerut, U.P., India

CCorresponding Author's Email: kansalsaurabh513@gmail.com

Received 04 Aug 2015; Review Completed 25 Aug 2015; Accepted 26 August 2015, Available online 15 Sep 2015

\begin{abstract}
Cholecystitis is defined as inflammation of the gallbladder. Ninety percent of cases involve stones in the cystic duct and gall

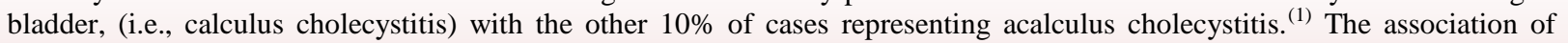
gallstones with Helicobacter pylori has been investigated but not clearly demonstrated. In this study, the presence of $\mathrm{H}$. pylori in the gallbladder mucosa of patients with symptomatic cholecystitis and cholelithiasis was investigated.The study included 50 cases of cholecystitis and cholelithiasis randomly selected who were admitted to the surgical wards of M.M.I.M.S.R, Mullana in last 2 years. All patients underwent cholecystectomy and gall bladder mucosa was histopathologically examined by giemsa staining (silver slide test). We concluded that no gall bladder mucosa exhibits presence of $\mathrm{H}$. Pylori.
\end{abstract}

Keywords: Cholelithiasis; Cholecystitis; H. pylori; Giemsa

\section{INTRODUCTION}

Cholecystitis is defined as inflammation of the gall bladder. Ninety percent of cases involve stones in the cystic duct and gall bladder, (i.e., calculus cholecystitis) with the other $10 \%$ of cases representing acalculus cholecystitis. ${ }^{1}$ The gallbladder mucosa secretes hydrogen ions and is covered by mucus. The environmental conditions for bacterial colonization are similar to those in the stomach. Gallbladder stones often contain DNA from enteric bacteria, but no compelling evidence demonstrates that Helicobacter spp. have been present. Gallstone disease is one of the most common problems affecting the digestive tract where autopsy reports show a prevalence of $11-36 \%$. The prevalence of gallstones is related to many factors including age, gender, and ethnic background. Women are three times more likely to develop gallstones than men and firstdegree relatives have a twofold increased prevalence. The association between Helicobacter pylori (H. pylori) and gallstones has been investigated but not clearly demonstrated. H.pylori closely correlates with chronic gastritis, peptic ulcer, gastric carcinoma and malignant lymphoma of gastric mucosa-related lymphoid tissues (MALToma). Recently, it has been found that $H$ pylori have certain relationship to some diseases in the organs besides the stomach and duodenum. However, it is still unclear whether $H$ pylori have any correlation with adjacent structures of the stomach, the liver and the gallbladder. There is little doubt that bacteria, including $H$ pylori, play a significant role in pigment gallstone formation. Bacterial genetic material has also been identified in pure and mixed cholesterol gallstones. Although, recent animal studies did not confirm any association between H.pylori infection and cholesterol gallstone formation, clinical studies have reached contradictory results, providing data in favour of or against the possible role of $H$ pylori as predisposing factor for cholesterol gallstone formation. ${ }^{2}$ The present study evaluates the incidence of presence of H.pylori in cases of cholecystitis and cholelithiasis in a rural setup.

\section{MATERIAL AND METHOD}

- The study included 50 cases of symptomatic cholecystitis and cholelithiasis, admitted to surgical wards of MMIMSR, Mullana (Ambala), Haryana, India in between October 2012 to October 2014. The cases were selected randomly and were proven cases of cholecystitis and cholelithiasis preoperatively. Preoperative biochemical investigations and ultrasound scanning were done to rule out any associated liver or extra-hepatic biliary disorder. Patients with Chronic pancreatitis, inflammatory bowel disease, Liver cirrhosis, Underlying malignancy, Familial hypercholesterolaemia were excluded. Patient 
Cases underwent laproscopic cholecystectomy and open cholecystectomy wherever indicated. Postoperative gall bladder specimen mounted in $10 \%$ formelin and send for histopathological examination. Gall bladder mucosa stained by GIEMSA (Silver Slide Test) and observed under microscope.

- This study has been well approved by institutional ethical committee and all the clinical studies included in this research work has been standardized according to the guidelines of ICMR,

\section{RESULTS:}

A total of 50 patients operated had 38 (76\%) females and $12(24 \%)$ males. The majority of patients $28(56 \%)$ were in the age group of 40 to 60 years. All 50 patients went through either open cholecystectomy or laproscopic cholecystectomy, Pain abdomen, nausea, vomiting, fever and dyspepsia were observed in $100 \%$, $18 \%, 10 \%, 18 \%, 16 \%$ respectively. On histopathological examination no gall bladder mucosa exhibits H.pylori in GIEMSA Staning. All 50 patients were negative by Silver Slide Test.

Table 1: Gender Distribution of patients

\begin{tabular}{|l|l|l|}
\hline MALE & FEMALE & TOTAL \\
\hline 12 & 38 & 50 \\
\hline
\end{tabular}

Table 2: Results of silver slide test according to gender

\begin{tabular}{|l|l|c|}
\hline $\begin{array}{c}\text { Result of silver } \\
\text { slide test }\end{array}$ & MALE & FEMALE \\
\hline Positive & 00 & 00 \\
\hline
\end{tabular}

Table 3: Overall reasult of silver slide test

\begin{tabular}{|l|l|c|}
\hline Positive & \multicolumn{1}{|c|}{ Negative } & Overall positive \\
\hline 00 & 50 & 00 \\
\hline
\end{tabular}

\section{DISCUSSION}

Cholecystitis is defined as inflammation of the gallbladder. Ninety percent of cases involve stones in the cystic duct and gall bladder, (i.e., calculus cholecystitis) with the other $10 \%$ of cases representing acalculus cholecystitis. ${ }^{(1)}$ The association of gallstones with Helicobacter pylori has been investigated but not clearly demonstrated. H. pylori present in human bile samples might represent a risk factor for gallstone formation. These reports stimulated interest as to whether these organisms colonize the biliary tract of humans and cause hepatobiliary diseases. The evidence, however, concerning the presence of Helicobacter in the bile and biliary tissue of human beings with biliary diseases is controversial ${ }^{3-6}$. H. pylori may be present in the bile when there are certain environmental changes, such as lowered pH. However, H. Pylori does not colonize the bile duct epithelium. They could find no pathogenetic role for $\mathrm{H}$. pylori in the formation of hepatolithiasis. $^{7}$ Helicobacter species are commonly present in the gallbladder of patients with gallstone diseases and in controls, implying that Helicobacter infection alone may not play a significant role in the formation of gallstones. However, their results do not exclude the possibility of Helicobacter infection as a cofactor in the development of gallstones. ${ }^{8}$ Helicobacter in gallstones of Iranian patients with biliary disease, gallstone and bile samples from 33 patients were subjected to rapid urease test, culture and Multiplex PCR. H. pylori was detected in stone samples of gallstones but not sure of their viability. ${ }^{9}$ The presence of few bacteria, the geographic distribution of $\mathrm{H}$. pylori strains, and the bile milieu inhibitory effect might be some of the reasons for growth failure. It concluded that although $\mathrm{H}$. pylori was detected by PCR in gallbladder tissue of patients with cholecystitis, a clinical correlation with biliary disease could not be established because several conditions were difficult to meet. ${ }^{10}$ Gallbladder tissue and bile specimens from subjects with H. pylori-positive gastritis with cholelithiasis. The presence of $\mathrm{H}$. pylori in antrum biopsies was confirmed by rapid urease test and/or histopathological examination. Helicobacter was detected in the gallbladder tissue and bile of $28 \%$ and $18 \%$ respectively of the patients, but was not detected in any of the gallstones. These results do not rule out the possibility of Helicobacter infection as a contributing agent or cofactor in the development of biliary diseases. ${ }^{11}$ Bostanoğlu E, Karahan ZC, Bostanoğlu A, Savaş B (2010) also did a study with aim to evaluate the presence of Helicobacter species in the gallbladder tissue, bile and gallstones of Turkish patients with cholelithiasis. Forty-seven patients with calculous cholecystitis and 3 controls were evaluated for the presence of Helicobacter spp. by culture, polymerase 
chain reaction, and histological and immunohistochemistry methods. Escherichia coli (10.6\%), Enterobacteramnigenus (6.3\%), Klebsiellaplanticola (2.1\%), and Klebsiellaozaenae $(2.1 \%)$ were isolated from the sample cultures of 8 patients. No other microorganisms, including $\mathrm{H}$. pylori and other Helicobacter spp., were detected. Polymerase chain reaction was negative for Helicobacter spp. and H. pylori. There was no association between the presence of Helicobacter spp. and development of cholelithiasis in this study group. The microorganisms found in the samples did not reveal any significant association with the underlying disease. ${ }^{12}$ Figura et al. (1998) who proposed that H. pylori present in human bile. In some studies, the presence of intestinal Helicobacter spp. H. pylori was detected in bile and /or gallbladder. The role of Helicobacter in the pathogenesis of gallbladder disease in humans, or even its presence in gallbladder tissue, therefore remains unclear. ${ }^{13}$ Bansal et al 2012 examined patients having mean (SD) age of 42.4 (11.1) years. Urea breath test was positive in $17(34.6 \%)$ cases. Rapid urease test was negative in all the cases. There was no evidence of $\mathrm{H}$. pylori infection of gallbladder on histopathological examination using H\&E, Giemsa and Warthin Starry stains. H. pylori DNA were detected in 16 patients $(32.6 \%)$ and none of the 12 controls by PCR analysis $(p=0.025)$. The presence of $H$. pylori DNA in bile and/or gallbladder was associated with positive urea breath test, $(p<0.0001)$. Other factors like age, gender, jaundice and cholestasis were not associated with $\mathrm{H}$. pylori infection of gallbladder and bile. ${ }^{14}$ Yakoob $\mathrm{J}$, Khan MR at el (2011) Helicobacter species colonise the biliary tract and therefore this study explores the relationship between of Helicobacter pylori and cholecystitis. Bile and gall bladder tissue samples were obtained from 144 patients who underwent cholecystectomy. Of these, 89 had chronic cholecystitis with cholelithiasis, 44 had gall bladder carcinoma and 11 had gall bladder polyps. Histopathology examination included special staining and immunohistochemistry (IHC), while Helicobacter species (H. pylori, H. bilis and $\mathrm{H}$. hepaticus) were detected by the polymerase chain reaction (PCR). Sequencing and BLAST query of PCR products was undertaken and samples were considered to contain H. pylori if both PCR and IHC were positive. Immunohistochemistry for $\mathrm{H}$. pylori was positive in $22(25 \%)$ cases compared to five $(9 \%)$ in the control group $(\mathrm{P}=0.02)$. Testing $(\mathrm{PCR})$ for $16 \mathrm{~S}$ rDNA was positive in $23(26 \%)$ cases compared to six (11\%) controls $(\mathrm{P}=0.03)$. Negative PCR results were obtained for $\mathrm{H}$. bilis and $\mathrm{H}$. hepaticus. Twenty-four $(89 \%)$ were positive by both $16 \mathrm{~S}$ rDNA PCR and IHC for H. pylori $(\mathrm{P}<0.001)$. Both PCR for $16 \mathrm{~S}$ rDNA and IHC were positive in $21(24 \%)$ cases compared to five $(9 \%)$ controls $(\mathrm{P}=0.03)$. Sequencing of $16 \mathrm{~S}$ rRNA and glmM PCR products were consistent with $H$. pylori. In conclusion, H. pylori DNA was demonstrated in cases of chronic cholecystitis and gall bladder carcinoma associated with cholelithiasis, but this association requires further study. ${ }^{15}$ Xiao et al 2014 said that since the discovery of Helicobacter species in human biliary system, the association between Helicobacter species infection and cholangiocarcinoma is under debate. This meta-analysis aims to explore this issue. Literature search was carried out to identify all eligible articles. We performed overall meta-analysis of all included studies and subgroup analysis based on regional distribution. Subgroup analysis in the light of detection methods and specimens was also conducted. Ten casecontrol studies were included. Overall meta-analysis favoured a significant association between Helicobacter species infection and cholangiocarcinoma (cumulative OR $8.88,95 \%$ CI 3.67-21.49). Subgroup analysis based on geographic distribution indicated that Helicobacter species infection may serve as a risk factor not only in a region with high cholangiocarcinoma incidence (Asia, OR 6.68, 95\% CI 2.29-19.49) but also in low incidence region (Europe, OR 14.90, 95\% CI 4.79-46.35). The other subgroup analysis showed that PCR was the most effective and efficient method to detect Helicobacter species in surgically rejected tissue and bile. There was significant heterogeneity among studies and obvious publication bias. They concluded that our meta-analysis supports the possible association between Helicobacter species infection and cholangiocarcinoma. Further investigations are required to clarify the role of Helicobacter species in this malignancy ${ }^{16}$.

Detection of the presence of $\mathrm{H}$. pylori in bile can be done with different in the bile of Canadian patients with biliary disorders, whereas a completely methods, techniques used may be responsible for the difference in the reported studies which are far from being perfect. The best way to show $\mathrm{H}$. pylori is to grow $\mathrm{H}$. pylori in cultures, but H. pylori are extremely hard to culture due to the microaerophilic properties of this microorganism, which die when they contact air. In another study it was shown that various PCR techniques could be used as a method for detection of H. pylori DNA in bile. Fallone et al. failed to find DNA of the genus Helicobacter contrary result was described by Silva et al. (who found bacterial nucleotide sequences in most Brazilian subjects with similar diseases). Regional differences due to variable rates of infection and the changing sensitivity of the various PCR ${ }^{17-18}$.

\section{CONCLUSION:}

The study did not depict presence of H.pylori in gall bladder mucosa by GIEMSA staning alone. Further investigations are required to clarify the presence of Helicobacter species in cases of cholecystitis and cholelithiasis. 


\section{REFERENCES}

1. Huffman JL, Schenker S. Acute acalculous cholecystitis - a review. Clin Gastroenterol Hepatol. Clin Gastroenterol Hepatol 2010;8(1):15-22.

2. Apostolov E, Al Soud WA, Nilsson I, Kornilovska I, Usenko $\mathrm{V}$, Lyzogubov $\mathrm{V}$, et al. Helicobacter pylori and other Helicobacter species in gall bladder and liver of patients with chronic cholecystitis detected by immunological and molecular methods. Scand J Gastroenterol 2005;40(1):96102.

3. Mendez-Sanchez N, Pichardo R, Gonzalez J, Sanchez H, Moreno M, Barquera F, et al. Lack of association between Helicobacter species colonization and gall stone disease. J Clin Gastroenterol 2001;32:138-41.

4. Cotticelli, L; Borrelli, M; d'Alessio, AC; Menzione, M; Villani, A; Piccolo,G; Montella, F; Iovene, MR; Romano, M. Central serous chorioretinopathy and Helicobacter pylori. European journal of ophthalmology. 2006; 16 (2): 274-8.

5. Blaser M. J "Who are we? Indigenous microbes and the ecology of human diseases". EMBO Reports 2006; 7 (10): 956-60.

6. Kawaguchi M, Saito T, Ohno H, Midorokawa S, Sanji T, Handa Y, et al. Bacteria closely resembling Helicobacter pylori detected immunohistologically and genetically in resected gall bladder mucosa. J Gastroenterol 1996;31:294298.

7. Myung SJ et al. Detection of Helicobacter pylori DNA in human biliary tree and its association with hepatolithiasias. Digestive Diseases and Sciences 2000;45:1405-1412.

8. Wafi Attaallah, Nese Yener, M. Umit Ugurlu, Manuk Manukyan, Ebru Asmaz, A. Ozdemir Aktan Gallstones and Concomitant Gastric Helicobacter pylori Infection Gastroenterology Research and Practice Volume 2013; (10):1155-58
9. Farshad SH et al. Identification of Helicobacter pylori DNA in Iranian patients with gallstones. Epidemiology and Infection 2004;132:1185-1189.

10. Salih BA et al. Helicobacter pylori DNA in gallbladder tissue of patients with cholelithiasis and cholecystitis. Journal of Infection in Developing Countries 2009;3:856-859.

11. Griniatsos J; Sougioultzis S; Giaslakiotis K; Gazouli M, Prassas E; et al, DNA in human cholesterol gallstones," Scandinavian Journal of Gastroenterology. 2002; 37(2):112119.

12. Bostanoğlu E, Karahan ZC, Bostanoğlu A. Evaluation of the presence of Helicobacter species in the biliary system of Turkish patients with cholelithiasis. Turk J Gastroenterol 2010; 21(4):421-7.

13. Figura $\mathrm{N}$ et al. Most Helicobacter pylori-infected patients have specific antibodies, and some also have H. pylori antigens and genomic material in bile. Is it a risk factor for gallstone formation? Digestive Diseases and Sciences 1998; 43:854-62.

14. Bansal VK, Misra MC, Chaubal G, Datta Gupta S, Das B, Ahuja V, Sagar S. Indian J Gastroenterol. 2012 Apr;31(2):57-60

15. Yakoob J, Khan MR, Abbas Z, Jafri W, Azmi R, Ahmad Z, Naeem S, Lubbad L. Br J Biomed Sci.2011;68(2):59-64.

16. Xiao M, Gao Y, Wang Y. Helicobacter species infection may be associated with cholangiocarcinoma: a meta-analysis : International Journal of Clinical Practice. 2014 feb;68(2):262270.

17. Silva CP, Pereira-Lima JC, Oliveira AG, Guerra JB, Marques DL, Sarmanho L, et al. Association of the presence of Helicobacter in gall bladder tissue with cholelithiasis and cholecystitis. J Clin Microbiology 2003;41:5615-8.

18. Fallone CA, Tran S, Semret M, Discepola F, Behr M, and Barkun AN, "Helicobacter DNA in bile: correlation with hepato-biliary diseases," Alimentary Pharmacology and Therapeutics, vol. 17, no. 3, pp. 453-458, 2003. 